\title{
The role of oxytocin in the pathogenesis and treatment of schizophrenia
}

\author{
Rola oksytocyny w patogenezie i leczeniu schizofrenii
}

\section{Katarzyna Jusiak ${ }_{\mathrm{ABEF}}$, Żaneta Brudkowska ${ }_{\mathrm{ABEF}}$, Maria Gołębiowska ${ }_{\mathrm{B}}{ }_{\text {, }}$, Justyna Morylowska - Topolska ${ }_{\mathrm{ABF}}$, Beata Gołębiowska ${ }_{\mathrm{AB}}$, Michał Próchnicki ${ }_{\mathrm{B}}^{2}$, Agnieszka Próchnicka ${ }_{\mathrm{B}}^{4}$, Hanna Karakuła - Juchnowicz ${ }_{\mathrm{ABF}}$}

${ }^{1}$ I Department of Psychiatry, Psychotherapy and Early Intervention, Medical University of Lublin

2 Department of Clinical Neuropsychiatry, Medical University of Lublin

3 Department of Pediatric Neurology, III Chair of Pediatrics, Medical University of Lublin

${ }^{4}$ Institute of Pedagogy of the Maria Curie-Skłodowska University in Lublin

Abstract

Introduction: Until recently, oxytocin was mainly associated with the pathophysiology of childbirth and sexual functions, but lately this hormone has become the object of interest to psychiatry and psychology due to the significant influence of oxytocin on human behavior in the field of social and emotional functioning. Current scientific research focuses on the participation of oxytocin in the pathogenesis and therapy of mental disorders.

Aim: The aim of the paper is to present, on the basis of available literature, the significance of oxytocin for various psychological functions, with particular emphasis on the influence of oxytocin on the course and clinical picture of schizophrenia.

Method: Available articles from the Medline / PubMed database were analyzed, which were searched using keywords: oxytocin, schizophrenia, therapeutic use of oxytocin, social cognition, positive symptoms, negative symptoms and time descriptors: 2013-2017. There are included articles published in Polish and English.

Results:The research results carried out so far suggest that oxytocin plays a significant role in modulating complex socio-emotional behaviors in schizophrenic patients. The existing research results also indicate a relationship between the dysregulation of the oxytocinergic system and the pathophysiology of schizophrenia. Many of the studies prove that there is a relationship between the level of oxytocin in the patients' blood plasma and the severity of the disease symptoms. Recent genetic studies indicate a possible relationship between polymorphism of oxytocingenesand polymorphism of oxytocin receptor genes and the risk of developing schizophrenia.

Conclusions: Contemporary research on the therapeutic potential of oxytocin and its influence on the functioning of schizophrenia patients seem to be very promising and may contribute to increasing the effectiveness of treatment of schizophrenia and possibly other mental disorders, which in turn will improve the quality of life of patients in cognitive, social and emotional functioning.

Keywords: oxytocin, schizophrenia, cognitive processes, social cognition, therapeutic use of oxytocin

\section{Streszczenie}

Wstęp: Do niedawna oksytocynę wiązano głównie z patofizjologią porodu oraz funkcjami seksualnymi, jednak w ostatnich latach, hormon ten stał się obiektem zainteresowania psychiatrii i psychologii ze względu na znaczący wpływoksytocyny na ludzkie zachowanie w zakresie funkcjonowania społecznego oraz emocjonalnego. Aktualnie prowadzone badania naukoweskupiają swoją uwagę na udziale oksytocyny w patogenezie i terapii zaburzeń psychicznych.

Cel pracy: Celem artykułu jest przedstawienie na podstawie dostępnej literatury znaczenia oksytocyny dla różnych funkcji psychicznych, ze szczególnym uwzględnieniem wpływu oksytocyny na przebieg i obraz kliniczny schizofrenii.

Metoda: Analizie poddano dostępne artykuły z bazy Medline/PubMed, które wyszukano przy użyciu słów kluczy: oksytocyna, schizofrenia, terapeutyczne zastosowanie oksytocyny, poznanie społeczne, objawy pozytywne, objawy negatywne i deskryptorów czasowych: 2013-2017. Uwzględniono artykuły opublikowane w języku polskim i języku angielskim.

Wyniki: Dotychczasowe wyniki badań sugerują, iż oksytocyna odgrywa znaczącą rolę w modulowaniu złożonych zach owań społeczno emocjonalnych u osób chorych na schizofrenię. Istniejące wyniki badań wskazują również na związek pomiędzy dysregulacją systemu oksytocynergicznego a patofizjologią schizofrenii. Wiele przeprowadzonych badań dowodzi, iż istnieje związek między poziomem stężenia oksytocyny w osoczu krwi pacjentów a nasileniem objawów choroby. Niedawne badania genetyczne wskazują na możliwy związek między polimorfizmem genów oksytocyny i polimorfizmem genów receptorów oksytocyny a ryzykiem zachorowania na schizofrenię.

Wnioski: Współczesne badania nad potencjałem terapeutycznym oksytocyny i jej wpływem na funkcjonowanie chorych na schizofrenię wydają być bardzo obiecujące i mogą przyczynić się do zwiększenia efektywności leczenia schizofrenii oraz być może innych zaburzeń psychicznych, co z kolei wpłynie na poprawę jakości życia pacjentów w zakresie funkcjonowania poznawczego, społecznego oraz emocjonalnego.

Słowa kluczowe: oksytocyna, schizofrenia, procesy poznawcze, poznanie społeczne, terapeutyczne zastosowanie oksytocyny

(C) 2017 Medical University of Lublin. This is an open access article distributed under the Creative Commons Attribution-NonComercial-No Derivs licence (http://creativecommons.org/licenses/by-nc-nd/3.0/) 


\section{Introduction}

Until recently, oxytocin was mainly associated with the pathophysiology of childbirth and sexual functions [1], but in lately this hormone has become the object of interest of many researchers representing various fields of science, including psychiatry and neuropsychology, mainly due to the significant impact on human behavior in social and emotional functioning [2]. Current scientific research is also focusing on the participation of oxytocin in the pathogenesis of mental disorders and on the possibilities of using this hormone in the therapy [3].The name of oxytocin (OT) comes from the Greek language and means "fast delivery" [4]. This phenomenon was discovered by Henry Dale in 1906, in the womb of a pregnant female cat [5.6]. The first particle of oxytocin was synthesized by Vincent duVigneaud in 1953, for which he was awarded the Nobel Prize two years later [7]. Although more than 100 years have passed since the discovery of oxytocin, it has become clear in recent years that oxytocin is of great importance for the processes related to social cognition [8], attachment [9], love [10], anxiety and cognitive processes [11], [12]. Its involvement in the pathogenesis of autism [13] schizophrenia [14] depression [15] and anorexia nervosa [16] has also been discovered.

\section{Aim:}

The aim of the article is to present, on the basis of available literature, the significance of oxytocin for various psychological functions, with particular emphasis on the influence of oxytocin on the course and clinical picture of schizophrenia.

\section{Method:}

Available articles from the Medline / PubMed database were analyzed, which were searched using key words: oxytocin, schizophrenia, therapeutic use of oxytocin, social cognition, positive symptoms, negative symptoms and time descriptors: 2013-2017. There are included articles published in Polish and English. Particular attention was paid to the latest reports on the role of oxytocin in the pathogenesis and treatment of schizophrenia. First, the functions performed by oxytocin are described and the sources of its formation are considered. Thereis presented oxytocin model of the formation of psychotic symptoms. Next, there are described studies on the influence of oxytocin on the course and clinical picture of schizophrenia as well as the possibilities and limitations of the use of this hormone in the treatment of psychiatric disorders, especially psychosis.

Oxytocin is a cyclic nonapeptideneurohormone that is secreted into the bloodstream by the nerve cells of the posterior pituitary gland[17]. Oxytocin secretion from the pituitary gland occurs as a result of irritation of nipple receptors or receptors of the cervix and vagina. The level of oxytocin in a woman's body is also regulated by hormones: estrogen increases its production and progesterone inhibits [18]. The basic functions of oxytocin are uterine contraction during delivery and transport of semen towards the fallopian tubes during sexual intercourse [18]. Oxytocin, like vasopressin, has various regulatory functions in the body. The action of these neurohormones at the level of the central nervous system is mainly related to the regulation of emotional and social processes [19]. Current research focuses on the participation of these hormones in the pathogenesis of mental disorders, potential use in diagnosis and therapy [20]. Oxytocin plays a significant role in the formation of social behaviors, starting from the attachment between mother and child [21]. At the same time, it should be noted that social contacts are the factor conditioning its release [19]. Importantly, oxytocin does not condition the attachment process but plays the role of modeling the attachment [22]. It is involved in the pathophysiology of mental disorders such as affective disorders, schizophrenia, and autism [23]. It is a key mediator of complex emotional and social behavior, both in humans and in animals [24]. Oxytocin is also involved in sexual behavior and stress responses [19]. It reduces anxiety, aggression and stress [23]. This happens with the participation of the amygdala and its connections to the brainstem and hypothalamus.

The neurons in the medial region of the amygdala are probably responsible for triggering the anxiety response. Oxytocin, while stimulating the external and lateral neurons, triggers GABA-ergic activity blocking the medial part [25]. In addition, oxytocin reduces the activity of the amygdala in response to stress caused by watching scenes of violence [8]. Some studies have shown that the effect of this neuropeptide on the amygdala depends on sex. Intranasally administered oxytocin in women increased the activity of the amygdala, while in men - it decreased [26]. The authors suggest that these differences have evolutionary significance and result from behaviors that women prefer - avoiding threats and ensuring a sense of security. A higher level of anti-oxytocin antibodies was found in aggressive people. [27]. What's more, oxytocin reduces anxiety levels, blood pressure, cortisol levels and accelerates wound healing [28]. It was observed that people who experienced childhood violence or other traumatic situations have lower levels of oxytocin [23]. These observations gave rise to attempts to use intranasally administered oxytocin to compensate its level in people who have experienced violence.

The treatment with intranasallyadministered oxytocin may therefore be beneficial in restoring an appropriate level of oxytocin in people who have experienced violence and may affect the process of rebuilding trust in 
other people and creating proper social bonds [23]. Some studies indicate an increase in oxytocin in the motherstouching their babies [29]. Similar situations are observed in women watching photos of their children or friends [30] and children in whom stress is relieved by the mother's touch or voice [31]. After taking oxytocin, the fathers became more forgiving and more willingly played with their children [32]. Other studies indicate a significant contribution of oxytocin in the processes of trust formation and intranasally administered oxytocin causes the faces shown in the pictures to be more friendly and attractive [33].

The role of oxytocin in the pathophysiology of schizophrenia - an oxytocin model of the formation of psychotic symptoms

The results of neuroimaging studies in healthy people indicate that endogenous oxytocin may modulate the activity of the brain structures associated with emotional and social behaviors: (amygdala, prefrontal cortex, temporal gyrus) [34].

Evidence from animal and human models suggests that dysregulation of the oxytocinergic system may play an important role in the pathophysiology of schizophrenia [35], affecting both positive [36] and negative [37, 38] symptoms.

Previous research results suggest that the main role of oxytocin in modulating complex social behaviors is related to the impact of this hormone on amygdala, by showing a decrease in anxiety [39]. In turn, in a neuroimaging study carried out in the group of healthy volunteers, it was proved that oxytocin affects the activation of the amygdala during exposure to unpleasant and pleasant stimuli, which indirectly influences the process of social learning [40]. The amygdala is therefore a significant area for the oxytocynergic system. It is believed that this structure is significantly involved in giving of the emotional significance both to single stimuli and complex social situations [41,42]. In addition, it is crucial for the process of perception of emotions and the ability of a human to assign meaning to the emotional states observed in other people [43]. Numerous neuroimaging studies indicate that functional and structural abnormalities of the amygdala have a significant role in the formation of emotional processesdysfunction, revealed by patients with schizophrenia $[44,45,46]$. An interesting proposal of a model shedding light on the importance of oxytocin in the formation of emotional disorders in schizophrenia was proposed in 2010 by Rosfeldet al. [47]. The authors suggest that the structural links of the amygdala and the dopaminergic system may be important in the therapy of schizophrenia. Therefore, in patients with schizophrenia who are taking anti-psychotics with anti-dopaminergic activity, impairment of capabilities in social cognition may occur [47]. Rosenfeld et al. formulated an "oxytocin model of the formation of psychotic symptoms", according to which "social cognitive deficits in schizophrenic patients are associated with impaired emotional information processing resulting from dysfunction in the amygdala.

The amygdala, as a place of processing and transmitting emotional information, may be dysfunctional in the course of schizophrenia. In schizophrenia, there may be disturbances in the interaction between the dopaminergic system, the amygdala and the oxytocinergic system. Irregularities related to oxytocin neurohormone can interfere with the functional activity of neurons, which causes incorrect attribution of the meanings of emotional information flowing from the external environment.

This may cause social cognition impairment and thus lead to abnormal social behavior, including withdrawal from social contacts, isolation, formulating paranoid judgements and delusions "[47, 48]. The same team of researchers emphasizes that further research is needed on the importance of oxytocin in modulating psychotic disorders, which would allow broadening knowledge on this subject.

Clarification is required on how and to what extent the level of concentration of oxytocin affects the social emotional behavior and which features of social cognition are susceptible to change under the influence of oxytocin. It is also important to determine the therapeutic potential of oxytocin in schizophrenia [47]. From the abovementioned studies on oxytocin, it appears that the role of oxytocin in schizophrenia should not be reduced only to its relationship with the emotional and social functioning of patients, but also to consider its participation in the pathogenesis of the disease $[49,50]$.This hypothesis is supported mainly by genetic and biochemical studies [51, 52 , 53]. Two variants of the oxytocin-related genes (rs4813625 and rs3761248) are specifically mentioned in the literature, which were significantly more frequent in the examined patients with schizophrenia than in the control group of healthy people [54]. However, recent genetic studies indicate a possible link between the polymorphism of the receptor-encoding genes for oxytocin and the risk of schizophrenia [53]. The results obtained by Souza et al. suggest a correlation between the oxytocin gene polymorphism (rs2740204) and the therapeutic response to clozapine and between the polymorphism of the oxytocin receptor gene (rs11706648, rs4686301, rs237899) and the severity of positive symptoms [55]. Authors of subsequent studies emphasize that disturbances in the regulation of the oxytocynergic system are associated with the pathophysiology of psychotic disorders $[47,56]$. It was found that patients diagnosed with schizophrenia had reduced blood plasma oxytocin concentration.This is particularly evident in patients with the 
PIP-syndrome: psychosis-intermittent hyponatremiapolydipsia) $[56,57]$.

The role of oxytocin in the formation of positive and negative symptoms in schizophrenia

Evidence of the presence of negative correlations between the level of endogenous oxytocin in plasma and the severity of positive and negative symptoms in schizophrenia suggest that oxytocin may contribute to the etiology of the disease $[58,59]$. It was proved that the low level of oxytocin in plasma was associated with exacerbation of schizophrenia symptoms in all three distinguished disease domains, i.e. positive and negative symptoms and cognitive-emotional functioning, although it should be noted that this correlation was more significant in relation to negative symptoms and relating to disorders of socio-cognitive functioning of patients $[58,60]$.

There are only a few works referring to the relationship of oxytocin with positive symptoms in schizophrenia. However, the results of research carried out in this area are not consistent. An example is the work of Rubin and colleagues. According to the authors, in patients diagnosed with schizophrenia, a higher level of oxytocin measured in the blood plasma was associated with a lower level of positive symptoms. Moreover, it was proved that estrogen and progesterone had the ability to regulate the level of endogenous oxytocin and the expression of its receptors [58]. Another study also reported a negative correlation between oxytocin level and the severity of positive symptoms in the group of schizophrenic patients [61]. However, another study by the same team of researchers did not confirm previous differences in oxytocin levels measured in blood plasma, at the same time there was no relationship between oxytocin level and the positive symptoms presented by the patients [62].

In contrast to the relatively sparse literature on the existence of reports on the relationship of oxytocin and the positive symptoms of schizophrenia, there are many reports indicating the relationship of oxytocin with the severity of negative symptoms. The results of these studies consistently confirm the negative relationship between oxytocin levels in the blood plasma and cerebrospinal fluid of patients and the severity of negative symptoms presented by them $[63,64]$. Keri et al. report that patients with schizophrenia compared to the control group, did not show an increase in the level of oxytocin measured in the blood plasma during experimental social interactions that required trust in another person [65]. The low level of oxytocin in the plasma of patients participating in this study was also associated with higher scores on the scale of negative symptoms (PANSS-N) especially with symptoms of social withdrawal, anhedonia and affective blunting [65].
In their study, Strauss and et al. also emphasize the relationship of endogenous oxytocin with negative symptoms in schizophrenia: low levels of this hormone were associated with increased frequency of antisocial behavior in patients with schizophrenia [26]. Furthermore, the results of genetic studies confirm the relationship of oxytocin with negative symptoms in schizophrenia .

In a study by Montag et al. , 2013, the correlation between the severity of negative symptoms and variants of the rs237902 gene for the oxytocin receptor (OXTR) was confirmed [53]. Similar results were obtained by Haram et al., where the rs53576 variant of the oxytocin receptor gene was associated with the behavioral symptoms of social withdrawal in schizophrenia [66].

\section{The role of oxytocin in the formation of disorders of social and emotional functioning}

Research on the importance of oxytocin in the course of schizophrenia is justified by the presence of emotional and social functioning disorders in patients, which constitute the axial behavioral feature of this disorder (according to the DSM-5 classification, the Diagnostic and Statistical Manual of MentalDisorder) [67]. The efficiency of cognitive functions and their relationship to social disorders in schizophrenia has been the subject of interest for researchers for decades, but research on these functions in schizophrenia has been relatively recently undertaken $[68,69,70]$. Social cognition, as a specific and unique aspect of cognitive functioning, seems to be a very important factor, for social functioning [71]. Social cognition manifests itself mainly by the ability to create effective relationships with other people and be at the disposal to enter into social interaction, is the sum of processes enabling people to live in the society [72]. The general definition of social cognition defines it as the ability to "think about other people" [73], while the detailed definition defines social cognition as "the ability to represent relationships between oneself and other people and the ability to apply these representations in social behavior" [74]. An interesting definition is the attempt to present social cognition as "mental operations that underlie social interactions, including human abilities to perceive intentions and other people's dispositions" [75] and as processes conditioning the type of reaction to other representatives of the same species [76].

These definitions combine social cognition and social behavior and include them in four components: emotional perception, social perception, theory of mind and attribution styles [77, 78, 79].

The most often studied phenomena belonging to social cognition are processes of Theory of Mind (ToM) [39]. The Theory of Mind is defined as the ability to represent one's own mental states and other people's mental states, 
and as the ability to determine relationships between them in the context of other behaviors revealed by others [80].

However, in order to describe the ability to interpret the behavior of others in terms of their beliefs, desires, feelings, needs, thoughts, intentions, the concepts of the theory of mind and mentalisation, are used interchangeably [81]. Research indicates the presence of disorders of these two skills in patients with schizophrenia [82]. Significant weakening of mentalisation mechanisms has been proven in schizophrenia, significantly higher during exacerbations of the disease, than during remission [83]. Recent research confirms that in the case of schizophrenia there is a significant ToM deficit [84]. In addition, the higher level of oxytocin measured in the blood plasma of patients diagnosed with schizophrenia was associated with better efficiency of functions creating the ability ofsocial cognition skills; patients with higher endogenous oxytocin levels also showed more pro-social behavior the regularity was found in both the studied group of women and men [58]. Recent studies also support the thesis that oxytocin is important as a hormone that supports the efficiency of social cognition skills in the course of schizophrenia.It has been proven that low level of endogenous oxytocin in the subjects was associated with the weakening of social cognition skills such as: adequate recognition of emotions based on facial observations $[59,85,86]$, understanding of abstract aspects of social interactions and mental states of other people, theory of mind $[87,88]$. Genetic research also supports the participation of oxytocin in the processes of social cognition in the course of schizophrenia. A recently published study by Davis et al., reported a significant relationship between the occurrence of the oxytocin gene receptor variant (rs2268493) and a weaker outcome in tasks measuring the efficiency of social cognition function, impaired mentalization and social perception [89].Nevertheless, the cognitive deficit in schizophrenia concerns both the above - social aspects of cognitive functioning [90] as well as non-social cognitive processes [91]. It is known that oxytocin is associated with cognitive processes such as spatial and episodic memory and cognitive flexibility [58]. Frost et al., noted a significant relationship between the low blood plasma levels of oxytocin in patients with schizophrenia and the presence of disturbances in the processes of information processing speed and work memory [92].

Recent research shows that there is a positive relationship between the increase of oxytocin in peripheral blood and the efficiency of cognitive functions, especially verbal and working memory $[60,93,94]$.

The results of previous studies indicate that oxytocin affects both positive and negative symptoms as well as cognitive and emotional functioning revealed in schizophrenia. This suggests that it may also play an important role in the etiology, and perhaps even effective treatment of this disease [50].

\section{Possibilities of therapeutic use of oxytocin in schi- zophrenia}

Earlier research on the function of oxytocin in schizophrenia has led researchers to seek therapeutic options for the use of this neuropeptide in the treatment of psychotic symptoms, and already in the 1970s, the first mention of the antipsychotic effect of oxytocin appeared [95]. The results of studies conducted by Bujanów indicated a beneficial effect of oxytocin in the treatment of acute schizophrenia, and to a lesser extent, in the treatment of chronic schizophrenia [96]. Bujanow's studies indicate that oxytocin administeredintravenously (10 IU - 15 IU) and intramuscularly (20 IU - $25 \mathrm{IU}$ ), once a day for 6-10 days, showed a rapid therapeutic effect, preventing further hospitalizations in patients with schizophrenia by reducing severity of symptoms of apathy and depression [95]. The development of the therapeutic use of oxytocin to treat the psychotic symptoms gained momentum after it has become possible to use oxytocin intranasally.Originally, it was attempted to use oxytocin in this form in gynecology and obstetrics, envisaging benefits in the treatment of lactation disorders in women after childbirth. However, the expected effect of increasing lactation has not been confirmed in clinical trials [97].

On the other hand, in the area of psychiatry, it was found that peripherally administered oxytocin inhibits the secretion of dopamine in the mesolimbic tract [98]. The results obtained in 2007 by Domes et al. were the first report on the therapeutic effect of oxytocin on cognitive functioning referred to as Theory of Mind (ToM). The study showed that single intranasal administration of oxytocin is sufficient to significantly improve the ability of affective mentalization and the ability to read subtle social signals by observing the eyes of others in the Reading the Mind in the Eyes Test (RMET) [99].

The results of the later studies indicate the beneficial effect of intranasal administration of oxytocin on reducing the severity of psychotic symptoms [58, 94].

Current research shows that patients with schizophrenia receiving intranasal oxytocin, after 2 weeks of therapyhave better results in terms of verbal memory and present improvement in the area of social behavior than patients receiving only psychoactive drugs [55]. Fejfel et al., also indicate a favorable effect of oxytocin administration in the reduction of both positive and negative symptoms [100]. Currently, many studies are conducted to find links between different variants of the oxytocin gene (chromosome 20) and the oxytocin receptor gene, and the tendency to develop schizophrenia and the course of its treatment $[108,109,110,111]$. 
In addition, antipsychotics have been reported to raise both central and peripheral oxytocin levels in patients [102]. It should be noted that the response to the treatment of psychotic symptoms with oxytocin is a very individual issue and depends on three factors: sex, hormonal status of patients and genetic variation of oxytocin receptor [103].

Like all treatments, also the oxytocin therapy has its limitations [104]. Among the side effects, the authors mention cognitive disorders in terms of memorization [105], as well as the possibility of disrupting the formation of distrust as a defense mechanism [106] and excessive activity in the sphere of sexual behavior [107].

Despite the promising results of oxytocin therapy, there are still many questions. For example, will there be a similar effect of treatment with oxytocin in the treatment of other psychoses than schizophrenia, such as, psychotic depression or bipolar disorder with psychotic symptoms. Does the improvement of the functioning of patients in terms of social, emotional and cognitive functioning appear only during antipsychotic treatment combined with oxytocin supplementation or is it possible to apply monotherapy with this hormone, and finally, can oxytocin be the treatment of choice of the periods of prodromal psychotic syndromes?

\section{Conclusions}

The above results indicate that oxytocin, which in classical terms was associated with biological processes such as childbirth or sexual intercourse, today also intrigues psychologists and psychiatrists due to its significant contribution to the pathogenesis of many mental disorders.

Currently, clinical studies are being carried out, focusing on the possibilities of using this neuropeptide in the treatment of psychotic symptoms, with particular emphasis on schizophrenia. As it has been demonstrated, intranasal oxytocin reduces the severity of both positive and negative symptoms in schizophrenia, and also improves cognitive, social and emotional processes in these patients. Despite the aforementioned limitations in the use of oxytocin for the treatment of psychotic disorders, further research in this area may contribute to increasing the effectiveness of treatment of schizophrenia and possibly other mental disorders, which in turn will improve the quality of life of patients in terms of social and emotional functioning.

\section{Wstęp}

Do niedawna oksytocynę wiązano głównie z patofizjologią porodu oraz funkcjami seksualnymi [1], jednak w ostatnich latach hormon ten stał się obiektem zainteresowania wielu zespołów badaczy reprezentujących różne dziedziny nauki, w tym psychiatrii i neuropsychologii, głównie ze względu na znaczący wpływ na ludzkie zachowanie $\mathrm{w}$ zakresie funkcjonowania społecznego oraz emocjonalnego [2]. Aktualnie prowadzone badania naukowe skupiają swoją uwagę także na udziale oksytocyny w patogenezie zaburzeń psychicznych oraz na możliwościach wykorzystania tego hormonu wich terapii[3]. Nazwa oksytocyna (OT) pochodzi z języka greckiego i oznacza „szybki poród”[4]. Substancję tę odkrył Henry Dale w 1906 roku, w macicy ciężarnej kotki [5,6]. Jako pierwszy cząsteczkę oksytocyny zsyntetyzował Vincent duVigneaud w 1953 roku, za co dwa lata później został uhonorowany Nagrodą Nobla [7]. Choć minęło ponad 100 lat od odkrycia oksytocyny, dopiero w ostatnich latach stało się jasne, iż oksytocyna ma ogromne znaczenie dla procesów związanych między innymi z poznaniem społecznym [8], przywiązaniem [9], miłością [10], lękiem i procesami poznawczymi [11,12]. Odkryto także jej udział w patogenezie autyzmu [13] schizofrenii [14] depresji [15], jadłowstrętu psychicznego [16].

Cel:

Celem artykułu jest przedstawienie na podstawie dostępnej literatury znaczenia oksytocyny dla różnych funk- cji psychicznych, ze szczególnym uwzględnieniem wpływu oksytocyny na przebieg i obraz kliniczny schizofrenii.

\section{Metoda:}

Analizie poddano dostępne artykuły z bazy Medline/PubMed, które wyszukano przy użyciu słów kluczy: oksytocyna, schizofrenia, terapeutyczne zastosowanie oksytocyny, poznanie społeczne, objawy pozytywne, objawy negatywne i deskryptorów czasowych: 2013-2017. Uwzględniono artykuły opublikowane $\mathrm{w}$ języku polskim i języku angielskim. Szczególną uwagą objęto najnowsze doniesienia dotyczące roli oksytocyny w patogenezie i leczeniu schizofrenii.Na wstępie opisano funkcje pełnione przez oksytocynę oraz uwzględniono źródła jej powstawania. Przedstawiono oksytocynowy model powstawania objawów psychotycznych. Następnie opisano badania dotyczące wpływu oksytocyny na przebieg i obraz kliniczny schizofrenii oraz możliwości i ograniczenia wykorzystania tego hormonu w terapii zaburzeń psychicznych, szczególnie psychoz.

Oksytocyna jest cyklicznym nonapeptydowym neurohormonem, który wydzielany jest do krwioobiegu przez komórki nerwowe tylnego płata przysadki mózgowej [17]. Wydzielanie oksytocyny z części nerwowej przysadki następuje $\mathrm{w}$ wyniku podrażnienia receptorów brodawek sutków lub receptorów szyjki macicy i pochwy. Poziom oksytocyny w organizmie kobiety jest także regulowany 
przez hormony: estrogen wzmaga jej wytwarzanie, a progesteron hamuje [18]. Podstawowymi funkcjami jakie pełni oksytocyna jest skurcz macicy podczas porodu oraz transport nasienia $\mathrm{w}$ kierunku jajowodów podczas stosunku płciowego [18]. Oksytocyna, podobnie jak wazopresyna, pełni w organizmie różne funkcje regulacyjne. Działanie tych neurohormonów na poziomie ośrodkowego układu nerwowego wiąże się głównie z regulacją procesów emocjonalnych i społecznych [19]. Aktualnie prowadzone badania skupiają się na udziale tych hormonów w patogenezie zaburzeń psychicznych, potencjalnych możliwościach wykorzystania ich $\mathrm{w}$ procesie diagnozy i terapii [20]. Oksytocyna odgrywa znaczną rolę w formowaniu zachowań społecznych, począwszy od zjawiska przywiązania pomiędzy matką a dzieckiem [21]. Należy jednocześnie zauważyć, że kontakty społeczne są czynnikiem warunkującym jej uwalnianie [19]. Co istotne, oksytocyna nie warunkuje procesu przywiązania, a pełni rolę modelującą przywiązanie [22]. Jest zaangażowana $\mathrm{w}$ patofizjologię zaburzeń psychicznych takich jak: zaburzenia afektywne, schizofrenia, autyzm[23].

Jest kluczowym mediatorem złożonych zachowań emocjonalnych i socjalnych, zarówno u ludzi jak i u zwierząt[24]. Oksytocyna jest również zaangażowana w zachowania seksualne i reakcje stresowe [19]. Zmniejsza poziom lęku, agresji i stresu [23]. Dzieje się tak przy udziale ciała migdałowatego oraz jego połączeń z pniem mózgu i podwzgórzem.

Za wyzwalanie odpowiedzi lękowej prawdopodobnie odpowiadają neurony okolicy przyśrodkowej jądra migdałowatego. Oksytocyna zaś pobudzając neurony okolicy zewnętrznej i bocznej wyzwala aktywność GABAergicznąblokującą cześć przyśrodkową [25]. Ponadto, oksytocyna zmniejsza aktywność ciała migdałowatego w odpowiedzi na stres wywołany oglądaniem scen przemocy [8]. Niektóre badania wykazały, że wpływ tego neuropeptydu na ciało migdałowate jest zależny od płci donosowo podana oksytocyna u kobiet podwyższała aktywność ciała migdałowatego, u mężczyzn zaś zmniejszała[26]. Autorzy pracy sugerują, że te różnice mają znaczenie ewolucyjne i wynikają z zachowań, które preferują kobiety - unikanie zagrożeń i zapewnienie poczucia bezpieczeństwa. Stwierdzono wyższy poziom przeciwciał przeciwko oksytocynie u osób agresywnych. [27]. Co więcej, oksytocyna obniża poziom lęku, ciśnienie krwi, poziom kortyzolu oraz przyśpiesza gojenie się ran [28]. Zaobserwowano, że u osób, które w dzieciństwie doświadczyły przemocy lub innej traumatycznej sytuacji stwierdza się niższy poziom oksytocyny [23]. Obserwacje te dały początek próbom zastosowania donosowo podawanej oksytocyny w celu wyrównania jej poziomu u osób, które doświadczyły przemocy. Leczenie donosową podawaną oksytocyną może zatem okazać się korzystne w przywracaniu odpowiedniego poziomu oksytocyny u osób, które doświadczyły przemocy oraz może wpłynąć na proces odbudowy zaufania do innych ludzi i tworzenia prawidłowych więzi społecznych [23]. Niektóre badania wskazują na wzrost poziomu oksytocyny u matki dotykających swoje niemowlęta [29]. Podobne sytuacje obserwuje się u kobiet oglądających zdjęcia swoich dzieci lub przyjaciół [30] oraz dzieci, u których stres łagodzony jest dotykiem lub głosem matki [31]. Ojcowie po podaniu oksytocyny stawali się bardziej wyrozumiali i chętniej bawili się ze swoimi dziećmi [32]. Inne badania wskazują na istotny udział oksytocyny w procesach tworzenia zaufania i donosowo podawana oksytocyna sprawia, że twarze przedstawiane na zdjęciach wydają się bardziej przyjazne i atrakcyjne [33].

\section{Rola oksytocyny w patofizjologii schizofrenii - oksyto-} cynowy model powstawania objawów psychotycznych

Wyniki badań neuroobrazowych u osób zdrowych wskazują, iż endogenna oksytocyna może modulować aktywność struktur mózgowia, związanych z zachowaniami emocjonalno - społecznymi: (ciało migdałowate, kora przedczołowa, zakręt skroniowy) [34].

Dowody płynące z badań na modelach zwierzęcych oraz z udziałem ludzi sugerują, iż dysregulacja systemu oksytocynergicznego może odgrywać ważną rolę w patofizjologii schizofrenii [35], mając wpływ zarówno na objawy pozytywne [36] jak i negatywne $[37,38]$.

Dotychczasowe wyniki badań sugerują, iż główna rola oksytocyny $\mathrm{w}$ modulowaniu złożonych zachowań społecznych jest związana z oddziaływaniem tego hormonu naciało migdałowate wykazując obniżenie reakcji lękowej [39]. Z kolei w badaniu neuroobrazowym, przeprowadzonym w grupie zdrowychochotników dowiedziono, iż oksytocyna wpływa na aktywację ciała migdałowatego podczas ekspozycji na bodźce nieprzyjemne jak i przyjemne, przez co pośrednio wpływa również na proces społecznego uczenia się[40]. Ciało migdałowate jest więc obszarem znaczącym dla systemu oksytocynergicznego. Uważa się, iż struktura ta jest istotnie zaangażowana w nadawanie emocjonalnego znaczenia zarówno pojedynczym bodźcom, jak i złożonym sytuacjom społecznym $[41,42]$. Poza tym ma kluczowe znaczenie dla procesu percepcji emocji oraz zdolności człowieka do przypisywania znaczenia obserwowanym $\mathrm{u}$ innych stanom emocjonalnym [43]. Liczne badania neuroobrazowe wskazują, iż funkcjonalne i strukturalne zaburzenia ciała migdałowatego mają istotny udział w powstawaniu dysfunkcji procesów emocjonalnych, ujawnianych przez pacjentów ze schizofrenią $[44,45,46]$. Ciekawą propozycję modelu rzucającego światło na znaczenie oksytocyny w powstawaniu zaburzeń emocjonalnych w schizofrenii zaproponował w 2010 rokuRosenfeld 
i wsp. [47]. Autorzy sugerują, iż powiązania strukturalne ciała migdałowatego z układem dopaminergicznym mogą mieć znaczenie $\mathrm{w}$ terapii schizofrenii. W związku $\mathrm{z}$ tym, u pacjentów ze schizofrenią, którzy przyjmują leki przeciwpsychotyczne o działaniu antydopaminergicznym może dojść do utraty sprawności w zakresie zdolności wchodzących w skład poznania społecznego [47]. Rosenfeld i współpracownicy sformułowali „oksytocynowy model powstawania objawów psychotycznych”, wg którego „deficyty poznania społecznego u chorych na schizofrenięłączą się z zaburzeniami przetwarzania informacji emocjonalnej, wynikając $\mathrm{z}$ dysfunkcji $\mathrm{w}$ zakresie ciała migdałowatego.

Ciało migdałowate, jako miejsce przetwarzania i przekazywania informacji emocjonalnej, może podlegać dysfunkcji w przebiegu schizofrenii. W schizofrenii może dochodzić zatem do zaburzeń interakcji pomiędzy układem dopaminergicznym, ciałem migdałowatym oraz układem oksytocynergicznym. Nieprawidłowości dotyczące neurohormonu oksytocyny mogą zakłócaćaktywność funkcjonalną neuronów, co powoduje nieprawidłowe przypisywanie znaczeń informacji emocjonalnej płynącej ze środowiska zewnętrznego.

Może to powodować zaburzenia poznania społecznego i tym samym prowadzić do nieprawidłowych zachowań społecznych, a w tym wycofywania się z kontaktów społecznych, izolacji, formułowania sądów paranoicznych oraz urojeń" [47, 48]. Ten sam zespół badaczy podkreśla,iż konieczne są kolejne badania nad znaczeniem oksytocyny w modulowaniu zaburzeń psychotycznych, które pozwoliłby na rozszerzenie wiedzy na ten temat. Dookreślenia wymaga chociażby to, w jaki sposób i w jakim stopniu poziom stężenia oksytocyny wpływa na zachowania społeczno - emocjonalne oraz które dokładnie funkcje poznania społecznego są wrażliwe na zmianę pod wpływem oksytocyny. Istotne również staje się określenie potencjału terapeutycznego oksytocyny w schizofrenii [47]. Z wyżej wymienionych opracowań dotyczących oksytocyny, wynika iż nie należy redukować roli oksytocyny w schizofrenii jedynie do jej związku z funkcjonowaniem emocjonalno - społecznym chorych, ale również rozpatrywać jej udział $\mathrm{w}$ samej patogenezie schorzenia $[49,50]$. Tę hipotezę wspierają głównie badania genetyczne i biochemiczne $[51,52,53]$. W literaturze szczególnie wymienia się dwa warianty genów związanych z oksytocyną (rs4813625 i rs3761248), które istotnie częściej występowały u badanych pacjentów ze schizofrenią, niż w grupie kontrolnej osób zdrowych [54]. Jednakże niedawne badania genetyczne wskazują na możliwy związek między polimorfizmem genów kodujących receptory dlaoksytocynya ryzykiem zachorowania na schizofrenię [53]. Wyniki badań uzyskane przez Souza i wsp. sugerują istnienie zależności między polimorfi- zmem genu dla oksytocyny (rs2740204) a odpowiedzią terapeutyczną na klozapinę oraz między polimorfizmem genudla receptora oksytocyny(rs11706648, rs4686301, rs237899) a nasileniem objawów pozytywnych [55]. Autorzy kolejnych badań podkreślają, iż zaburzenia w regulacji systemu oksytocynergicznego wiążą się z patofizjologią zaburzeń psychotycznych $[47,56]$. Stwierdzono, iż pacjenci z rozpoznaniem schizofrenii mają obniżone stężenie oksytocyny w osoczu krwi.Jest to szczególnie widoczne u pacjentów z towarzyszącym zespołem psychoza-hiponatremia-polidypsja(PIP-syndrome: psychosis-intermittenthyponatremia-polydipsia) $[56,57]$.

\section{Rola oksytocyny w powstawaniu objawów pozytyw- nych i negatywnych w schizofrenii}

Dowody na obecność korelacji o charakterze negatywnym pomiędzy poziomem endogennej oksytocyny w osoczu a nasileniem symptomów pozytywnych i negatywnych w schizofrenii sugerują, iż oksytocyna może mieć swój udział w etiologii schorzenia [58,59]. Dowiedziono, iż niski poziom oksytocyny $\mathrm{w}$ osoczu wiązał się $\mathrm{z}$ zaostrzeniem symptomów schizofrenii we wszystkich trzech wyróżnianych domenach choroby, tj. objawach pozytywnych, negatywnych oraz funkcjonowaniu poznawczo - emocjonalnym, choć należy zaznaczyć, iż korelacja ta była bardziej znacząca w odniesieniu do objawów negatywnych oraz wiążących się z zaburzeniami funkcjonowania społeczno - poznawczego pacjentów $[58,60]$.

Istnieje jedynie kilka prac nawiązujących do związku oksytocyny z objawami pozytywnymi w schizofrenii. Wyniki prowadzonych $\mathrm{w}$ tym zakresie badań nie są jednak spójne. Za przykład można podać prace Rubina i wsp. Jak donoszą autorzy, u pacjentek z rozpoznaniem schizofrenii wyższy poziom oksytocyny mierzonej w osoczu krwi wiązał się z mniejszym nasileniem objawów pozytywnych.Ponadto dowiedziono, iż estrogen oraz progesteron miał zdolność regulacji poziomu endogennej oksytocyny oraz ekspresji jejreceptorów [58]. W innej pracy również zaobserwowano związku ujemną zależność pomiędzy poziomem oksytocyny a nasileniem objawów pozytywnych w grupie pacjentów ze schizofrenią[61]. Jednak kolejne badanie tego samego zespołu badaczy nie potwierdziło wcześniejszych różnic pod względem poziomu oksytocyny mierzonej w osoczu krwi, jednocześnie nie odnotowano związku pomiędzy poziomem oksytocyny a prezentowanymi przez chorych objawami pozytywnymi [62].

W przeciwieństwie do stosunkowo skąpej literatury dotyczącej istnienia doniesień na temat związku oksytocyny $\mathrm{z}$ objawami pozytywnymi $\mathrm{w}$ schizofrenii, istnieje wiele doniesień wskazujących na związek oksytocyny z nasileniem objawów negatywnych. Wyniki tych badań konsekwentnie potwierdzają negatywną zależność między poziomem oksytocyny w osoczu krwi oraz płynie 
mózgowo - rdzeniowym pacjentów a nasileniem prezentowanych przez nich objawów negatywnych [63,64].Keri i wsp. donoszą, iż pacjenci ze schizofrenią w porównaniu do grupy kontrolnej nie wykazywali wzrostu poziomu oksytocyny mierzonej w osoczu krwi podczas eksperymentalnych interakcji społecznych wymagających zaufania innej osobie [65]. Niski poziom oksytocyny w osoczu pacjentów biorących udział $\mathrm{w}$ tym badaniu wiązał się także z wyższymi wynikami w skali objawów negatywnych (PANSS-N) szczególnie $\mathrm{z}$ objawami społecznego wycofania, anhedonii oraz afektywnym stępieniem [65].

W badaniu Strauss i wsp.również podkreślają związek endogennej oksytocyny z objawami negatywnymi w schizofrenii: niski poziom tego hormonu wiązał się szczególnie z większą częstotliwością przyjmowaniapostaw aspołecznych przez pacjentów ze schizofrenią [26].Ponadto wyniki badań genetycznych potwierdzają związek oksytocyny z negatywnymi objawami w schizofrenii.

W badaniu Montag i wsp. z 2013 roku potwierdzono istnienie korelacji pomiędzy nasileniem objawów negatywnych a wariantami rs237902genu dlareceptoraoksytocyny (OXTR) [53]. Podobne wyniki uzyskał Haram i wsp., gdzie wariat rs53576genudlareceptora oksytocyny wiązał się ze behawioralnymi objawami społecznego wycofania wschizofrenii [66].

\section{Rola oksytocyny w powstawaniu zaburzeń funkcjo- nowania społeczno - emocjonalnego}

Badania nad znaczeniem oksytocyny w przebiegu schizofrenii uzasadnione są obecnością u chorych zaburzeń funkcjonowania emocjonalno -społecznego, które stanowiąosiową cechę behawioralną tego zaburzenia (wg klasyfikacji DSM-5, Diagnostic and Statistical Manual ofMentalDisorder) [67]. Sprawność funkcji poznawczych i ich związek z zaburzeniami społecznymi w schizofrenii od dziesięcioleci był przedmiotem zainteresowania badaczy, jednak stosunkowo niedawno podjęto badania w zakresie tych funkcji w schizofrenii $[68,69,70]$. Poznanie społeczne (socialcognition), jako specyficzny i unikalny aspekt funkcjonowania poznawczego, zdaje się być bardzo istotnym czynnikiem, mającym znaczenie dla funkcjonowania społecznego [71]. Poznanie społeczne przejawiasię głównie w umiejętności tworzeniaefektywnych relacji z innymi osobami orazw dyspozycji do wchodzenia w interakcje społeczne,jest sumą procesów umożliwiającychczłowiekowi życie w społeczeństwie [72]. Ogólna definicja poznania społecznego ujmuje je jako umiejętność „myślenia o innych ludziach” [73], natomiast definicja szczegółowa określa społeczne poznanie jako „zdolność do tworzenia reprezentacji relacji między sobą samym a innymi ludźmi oraz umiejętność płynnego stosowania tych reprezentacji w zachowaniu społecznym" [74]. Ciekawą definicją jest próba przedstawienia poznania społecznego jako „operacji umysłowych leżacych u podstaw interakcji społecznych, $w$ tym zdolności człowieka do postrzegania intencji i dyspozycji innych ludzi" [75] oraz jako procesów warunkujących typ reakcji na innych przedstawicieli tego samego gatunku [76]. Wymienione definicje łączą społeczne poznanie z zachowaniem społecznym i ujmują je w czterech komponentach: percepcji emocjonalnej, percepcji społecznej,teorii umysłu i stylach atrybucyjnych $[77,78,79]$.

Najczęściej badanymi zjawiskami należącymido poznania społecznego są procesy teoriiumysłu (Theory of Mind- ToM) [39].Teoria umysłu jest definiowana jako umiejętność reprezentowania własnych stanów mentalnych i stanów umysłowych innych osób oraz jako zdolność ustalania relacji między nimi w kontekście ujawnianego przez innych zachowania [80].

Niemniej jednak do opisu zdolności interpretowania zachowań innych w kontekście ich przekonań, pragnień, uczuć, potrzeb, myśli, intencji stosowane są zamiennie pojęcia teorii umysłu orazmentalizacji[81].Badania wskazują na obecność zaburzeń tych dwóch zdolności u chorych na schizofrenię [82]. Udowodniono znaczneosłabienie mechanizmów mentalizacji w schizofrenii, istotnie większew okresie nasilenia objawów choroby, niż w czasieremisji [83]. Najnowsze badaniapotwierdzają, iż w przypadku schizofrenii mamydo czynienia z istotnym deficytem ToM [84]. Ponadto wyższy poziom oksytocyny mierzonej $\mathrm{w}$ osoczu krwi pacjentów z rozpoznaniem schizofrenii wiązał się z lepszą sprawnością funkcji budujących zdolność poznania społecznego, pacjenci z wyższym poziomem endogennej oksytocyny wykazywali również częściej zachowania prospołeczne - prawidłowość występowała zarówno w badanej grupie chorych kobiet jak i mężczyzn [58]. Ostatnie badania także wspierają tezę o istotnym znaczeniu oksytocyny jako hormonu wspierającego sprawność funkcji poznania społecznego w przebiegu schizofrenii. Udowodniono, iż ubadanych niski poziom endogennej oksytocyny wiązał się z osłabieniem zdolności poznania społecznego takich jak: adekwatne rozpoznawanie emocji na podstawie obserwacji twarzy $[59,85,86]$, rozumienie abstrakcyjnych aspektów interakcji społecznych i stanów mentalnych innych osób, teorii umysłu [87, 88]. Badania genetyczne również wspierają udział oksytocyny w procesach poznania społecznego w przebiegu schizofrenii. W niedawno opublikowanym badaniu Davis i wsp. odnotowano istotny związekpomiędzy występowaniem wariantu receptora genu dla oksytocyny (rs2268493) a słabszym wynikiem w zadaniach mierzących sprawność funkcji poznania społecznego, osłabioną zdolnością mentalizacji i społecznej percepcji [89].Niemniej jednak deficyt poznawczy w schizofrenii dotyczy zarówno wyżej wymienionych - społecznych aspektów funkcjonowania poznawczego [90], jak również niespołecznych procesów poznawczych [91]. 
Wiadomo, iż oksytocyna wykazuje związektakże z procesami kognitywnymi takimi jak: pamięć przestrzenna i epizodyczna oraz elastyczność poznawcza [58]. Frost i wsp. odnotowali istotną zależność pomiędzy niskim poziomem oksytocyny w osoczu krwi pacjentów ze schizofrenią a obecnością zaburzeń procesów szybkości przetwarzania informacji oraz pamięci roboczej [92].

Najnowsze badania dowodzą, iż istnieje pozytywna zależność pomiędzy wzrostem poziomu oksytocyny we krwi obwodowej a sprawnością funkcji poznawczych, szczególnie pamięci werbalnej oraz roboczej [60, 93, 94].

Wyniki dotychczasowych badań wskazują, iż oksytocyna ma wpływ zarówno objawy pozytywne, negatywne jak i funkcjonowanie poznawczo - emocjonalne ujawniane w schizofrenii. Sugeruje to, że może ona również odgrywać ważną rolę w etiologii, a być może nawet skutecznym leczeniu tego schorzenia [50].

\section{Możliwości terapeutycznego zastosowania oksytocy- ny w schizofrenii}

Wcześniejsze wyniki badań dotyczące funkcji oksytocyny w schizofrenii skłoniły badaczy do poszukiwania terapeutycznych możliwości zastosowania tego neuropeptydu w leczeniu objawów psychotycznych, a już w latach 70 ubiegłego wieku pojawiła się pierwsza wzmianka o działaniu przeciwpsychotycznym oksytocyny [95]. Wyniki badań przeprowadzonych przez Bujanowa wskazywały na korzystny wpływ oksytocyny w leczeniu ostrej schizofrenii, i w mniejszym stopniu, w leczeniu schizofrenii przewlekłej [96]. Badania Bujanowa wskazują, iż oksytocyna podawana dożylnie (10 I.U. - 15 I.U.) oraz domięśniowo (20 I.U. - 25 I.U.), 1 raz dziennie,przez okres od 6 10 dni, wykazywała szybkie działanie terapeutyczne zapobiegając kolejnym hospitalizacjom u pacjentów z schizofrenią dzięki zmniejszeniu nasilenia objawów apatii i depresji[95].Rozwój nad terapeutycznym zastosowaniem oksytocyny w leczeniu objawów psychotycznych nabrał tempa, po tym jak pojawiła się możliwość zastosowania oksytocyny donosowo. Pierwotnie próbowano zastosować oksytocynę $\mathrm{w}$ takiej postaci w ginekologii i położnictwie, przewidując korzyści w zakresie leczenia zaburzeń laktacji u kobiet po porodzie. Spodziewany efekt wzmocnienia laktacji nie został jednak potwierdzony w badaniach klinicznych [97].

Z kolei w obszarze psychiatrii stwierdzono, że oksytocyna podana obwodowo hamuje sekrecję dopaminy w szlaku mezolimbicznym[98]. Rezultaty uzyskane w 2007 roku przez Domes i wsp. były pierwszym doniesieniem o terapeutycznym wpływie oksytocyny na funkcjonowanie poznawcze określane jako Teoria Umysłu(ToM). Badanie wykazało, iż pojedyncze donosowe podanie oksytocyny jest wystarczające, aby znacząco usprawnić zdolność afektywnej mentalizacji oraz umie- jętności odczytywania subtelnych społecznych sygnałów obserwując obszar oczu innych w teścieReading the Mind in the Eyes Test (RMET)[99].

Wyniki badań prowadzonych w późniejszym okresie wskazują na korzystny wpływ podania donosowego oksytocyny na zmniejszenie nasilenia objawów psychotycznych $[58,94]$.

Obecne badania pokazują, że pacjenci z rozpoznaniem schizofrenii przyjmujący donosowo oksytocynę, po 2 tygodniach terapii uzyskują lepsze wyniki w zakresie pamięci werbalnej i prezentują poprawę w obszarze zachowań społecznych, niż chorzy przyjmujący tylko leki p/psychotyczne [55]. Także badania Fejfel i wsp. wskazują na korzystny efekt podania oksytocyny w obrębie redukcji zarówno objawów pozytywnych jak i negatywnych [100]. Aktualnie prowadzonych jest wiele badań mających na celu znalezienie powiązań pomiędzy różnymi wariantami genu oksytocyny (chromosom 20) oraz genu receptora oksytocyny, a tendencją zachorowania na schizofrenię oraz przebiegiem jej leczenia $[108,109,110,111]$.

Ponadto zauważono, że leki przeciwpsychotyczne podnoszą zarówno centralny [101] iobwodowy poziom oksytocyny u pacjentów [102]. Warto zaznaczyć, iż odpowiedź na leczenie objawów psychotycznych oksytocyną jest kwestią bardzo indywidualną i zależną od trzech czynników: płci, statusu hormonalnego pacjentów oraz zmienności genetycznej receptora oksytocyny [103].

Podobnie jak każde leczenie, również terapia oksytocyną ma swoje ograniczenia [104]. Wśród objawów ubocznych autorzy badań wymieniają zaburzenia procesów poznawczych w zakresie zapamiętywania [105], a także możliwość zaburzenia procesu formowania nieufności jako mechanizmu obronnego [106] oraz nadmierną aktywność w sferze zachowań seksualnych [107].

Mimo obiecujących wyników terapią oksytocyny, nadal pozostaje jeszcze wiele pytań, między innymi: czy uzyska się podobny efekt leczenia oksytocyną w terapii innych psychoz niż schizofrenia, na przykład depresji psychotycznej czy chorobie afektywnej dwubiegunowej z objawami psychotycznymi, czy poprawa funkcjonowania pacjentów w zakresie funkcjonowania społecznego, emocjonalnego i poznawczego pojawia się tylko podczas leczenia przeciwpsychotycznego połączonego $\mathrm{z}$ suplementacją oksytocyny, czy istnieje możliwość monoterapii tym hormonem oraz w końcu, czy oksytocyna może być leczeniem z wyboru okresów prodromalnych zespołów psychotycznych?

\section{Podsumowanie}

Powyższe wyniki badań wskazują, iż oksytocyna, która w klasycznym ujęciu wiązana była $\mathrm{z}$ procesami biologicznymi takimi jak poród czy stosunek płciowy, dzisiaj intryguje także psychologów oraz psychiatrów 
z uwagi na jej znaczący udział w patogenezie wielu zaburzeń psychicznych.

Aktualnie prowadzone są badania kliniczne skupiające swoją uwagę na możliwości wykorzystania tego neuropeptydu w leczeniu objawów psychotycznych, ze szczególnym uwzględnieniem schizofrenii. Jak dowiedziono, podawana donosowo oksytocyna redukuje nasilenie zarówno objawów pozytywnych, jak i negatywnych w schizofrenii, a także usprawnia procesy poznawcze, społeczne oraz emocjonalne u tych pacjentów. Pomimo wspomnianych ograniczeń w zastosowaniu oksytocyny do leczenia zaburzeń psychotycznych, dalsze badania w tym zakresie mogą przyczynić się do zwiększenia efektywności leczenia schizofrenii oraz być może innych zaburzeń psychicznych, co z kolei wpłynie na poprawę jakości życia pacjentów w zakresie funkcjonowania społecznego oraz emocjonalnego.

\section{Conflict of interest}

The authors have declared no conflict of interest.

\section{References:}

1. Sogolow S.R. An historical review of the use of oxytocin prior to delivery. ObstetGynecolSurv. 1966; 21(2):155-72

2. Olff M., Frijling J. L., Kubzansky M., et al. The role of oxytocin in social bonding, stress regulation and mental health: an update on the moderating effects of context and interindividual differences. Psychoneuroendocrinology, 2013; 38(9), 1883-1894

3. Tachibana M., et al. Long-term administration of intranasal oxytocin is a safe and promising therapy for early adolescent boys with autism spectrum disorders. Journal of child and adolescent psychopharmacology, 2013; 23.2: 123-127

4. Jones R. E., Lopez K.H. Human reproductive biology. Academic Press, 2013; 303.

5. Burbach J.P., Young L.J, Russell J. Oxytocin: synthesis, secretion, and reproductive functions. In: Neill, JD., editor. Knobil and Neill's Physiology of Reproduction. Elsevier; New York; 2006. p. 3055-3127.

6. Dale H.H. On some physiological actions of ergot. J Physiol, 1906; 34:163-206.

7. Ross H.E., Young L.J. Oxytocin and the Neural Mechanisms Regulating Social Cognition and Affiliative Behavior, Front Neuroendocrinol, 2009; 30(4): 534-547

8. Kirsch P., et al. Oxytocin modulates neural circuitry for social cognition and fear in humans. Journal of neuroscience, 2005; 25.49: 11489-11493.

9. Buchheim A., et al. Oxytocin enhances the experience of attachment security. Psychoneuroendocrinology, 2009; 34.9: 1417-1422.

10. Carter, C. S., Porges S. W. The biochemistry of love: an oxytocin hypothesis. EMBO reports, 2013; 14.1: 12-16.

11. Labuschagne I., et al. Oxytocin attenuates amygdala reactivity to fear in generalized social anxiety disorder. Neuropsychopharmacology, 2010; 35.12: 2403-2413.

12. Kocoska-Maras L., et al. Cognitive function in association with sex hormones in postmenopausal women. Gynecological Endocrinology, 2013; 29.1: 59-62.
13. Bartz JA., Hollander E. Oxytocin and experimental therapeutics in autism spectrum disorders. Progress in Brain Research. 2008; 170: 451-62.

14. Gibson C.M. An investigation of the effects of oxytocin on social cognition and social functioning in schizophrenia. Diss. The University of North Carolina at Chapel Hill. 2012.

15. McQuaid, R. J. Making room for oxytocin in understanding depression. Neuroscience \&Biobehavioral Reviews. 2014; 45: 305-322.

16. Lawson E. A. Oxytocin secretion is associated with severity of disordered eating psychopathology and insular cortex hypoactivation in anorexia nervosa. The Journal of Clinical Endocrinology \& Metabolism. 2012; 97(10): 1898-1908.

17. Ganong W. Fizjologia. Warszawa: PZWL; 2007, s. 240.

18. Konturek S. Wydzielanie wewnętrzne. W: Traczyk W., Trzebski A. Fizjologia człowieka z elementami fizjologii stosowanej i klinicznej. Wyd. III. Warszawa: PZWL; 2007, s. 343-345.

19. Wójciak P., Remmlinger-Molenda A., Rybakowski J. The role of oxytocin and vasopressin in central nervous system activity and mental disorders. Psychiat. Pol. 2012; 46: 1043- 1052.

20. Wójciak P., Remlinger- Molenda A., Rybakowski J. Rola oksytocyny i wazopresyny w czynności ośrodkowego układu nerwowego i w zaburzeniach psychicznych. Psychiatr. Pol. 2012; 46 (6): 1044-1046.

21. Carter C.S. Neuroendocrine perspectives on social attachment and love. Psychoneuroendocrinol. 1998; 23: 779-818.

22. Bartz J., Zaki J., Ochsner K. et al. Effects of oxytocin on recollections of maternal care and closeness. Psychol. Cogn. Sc. 2010; 107 (50): 21371-21375.

23. Netheron E., Schatte D. Potential for oxytocin use in children and adolescents with mental illness. Hum. Psychopharmacol., 2011; 26: 271- 281.

24. Bosh O. J., Sartor S. B., Singewald N., Neumann I. D. Extracellular amino acid levels in the paraventricular nucleus and the central amygdala in high and low anxiety dams rats during maternal aggression: regulation by oxytocin. Stress., 2007; 10: 261-270.

25. Dębiec J. Peptides of love and fear; vasopressin and oxytocin modulate the integration of

information in the amygdala. BioEssays, 2005; 27: 869-873.

26. Strauss G.P., Keller W.R., Koenig J.I., Gold J.M., Ossenfort K.L., Buchanan R.W. Plasma oxytocin levels predict olfactory identification and negative symptoms in individuals with schizophrenia.Schizophrenia research, 2015; 162.1: 57-61.

27. Fetissov S.O., Hallman J., Nilsson I., Lefvert A.K., Oreland L. Hokfelt T. Aggressive behawior linked to corticotropin- reactive autoantibodies. Biol. Psychiatry., 2006; 60(8): 799-802.

28. Uvnas- Moberg K. Oxytocin may mediate the beneficts of positive social interaction and emotions. Psychoneuroendocrinol., 1998; 23(8): 819- 835.

29. Strathearn L., Fonagy P., Amico J., Montague PR. Adult attachment predicts maternal brain and oxytocin response to infant cues. Neuropsychopharmacol., 2009; 34(13): 2655- 2666.

30. Bartels A., Zeki S. The neural correlates of maternal and romantic love. Neuroim., 2004; 21(3): 1155- 1166.

31. Sltzer LJ., Zieger TE., Pollak S. Social vocalizations can release oxytocin in humans. Proc. Biol. S.C., 2010; 277.1694: 2661-2666.

32. Naber $F$., et al. Intranasal oxytocin increases fathers observed responsiveness during play with their children; a double- blind within- subject experiment. Psychoneuroendocrinol. 2010.35.10: 1583-1586.

33. Zaka P. J., Kurzband R., Matznere W. T. Oxytocin is associated with humans trust worthivess. Horm. Behav., 2005; 48: 522- 527

34. Bartholomeusz C. F., Ganella E. P., Labuschagne I., Bousman C., Pantelis C. Effects of oxytocin and genetic variants on brain and 
behaviour: implications for treatment in schizophrenia. Schizophrenia Research, 2015; 168(3), 614-627.

35. Feifel D., Reza T. Oxytocin modulates psychotomimetic-induced deficits in sensorimotor gating. Psychopharmacology, 1999; 141(1), 93-98.

36. Caldwell H. K., Stephens S. L.,Young W. S. Oxytocin as a natural antipsychotic: a study using oxytocin knockout mice. Molecular psychiatry, 2009;14(2), 190-196.

37. Meziane $\mathrm{H}$. et al. An early postnatal oxytocin treatment prevents social and learning deficits in adult mice deficient for Magel2, a gene involved in Prader-Willi syndrome and autism. Biological psychiatry, 2015; 78(2), 85-94.

38. Peñagarikano 0. et al. Exogenous and evoked oxytocin restores social behavior in the Cntnap2 mouse model of autism. Science translational medicine, 2015; 7(271), 271ra8-271ra8.

39. Wiener D., Rybakowski J. Zaburzenia poznania społecznego w schizofrenii. Psychiatr Pol, 2006; 40: 205-218.

40. Gamer, M. Does the amygdala mediate oxytocin effects on socially reinforced learning?. Journal of Neuroscience, 2010; 30.28: 9347-9348.

41. LeDoux, J.E., Emotion circuits in the brain. Annu. Rev. Neurosci., 2000; 23, 155-184.

42. Yaniv, D., Desmedt, A., Jaffard, R., Richter-Levin, G. The amygdala and appraisal processes: stimulus and response complexity as an organizing factor. Brain Res. Rev., 2000; 44: 179-186.

43. Shaw P. et al. The impact of early and late damage to the human amygdala on 'theory of mind' reasoning. Brain, 2004; 127: 1535-1548.

44. Anticevic A., et al. Amygdala recruitment in schizophrenia in response to aversive emotional material: a meta-analysis of neuroimaging studies. Schizophrenia bulletin, 2010, 38.3: 608-621.

45. Van Snellenberg, J.X., et al. Amygdala Recruitment in Schizophrenia in Response to Aversive Emotional Material: A MetaAnalysis of Neuroimaging Studies. In: Biological Psychiatry. 360 Park Ave South, New York, Ny 10010-1710 Usa: Elsevier Science Inc, 2011. P. 240s-240s

46. Wright I.C., Rabe-Hesketh S., Woodruff P.W., et al. Meta analysis of regional brain volumes in schizophrenia. Am. J. Psychiatry, 2000; 157: 16-25

47. Rosenfeld A.J., Lieberman J.A., Jarskog L.F. Oxytocin, dopamine, and the amygdala: a neurofunctional model of social cognitive deficits in schizophrenia. Schizophr Bull., 2011; 37:1077-87.

48. Holka-Pokorska J., Jarema M. Oksytocynowy model powstawania objawów psychotycznych a implikacje dla badań nad rolą systemu oksytocynergicznego w schizofrenii. Psychiatr. Pol, 2014; 48.1: 19-33.

49. Quintana D. S., et al. Oxytocin system dysfunction as a common mechanism underlying metabolic syndrome and psychiatric symptoms in schizophrenia and bipolar disorders. Frontiers in neuroendocrinology, 2017; 45: 1-10.

50. Rich M.E., Caldwell H. K. A role for oxytocin in the etiology and treatment of schizophrenia. Frontiers in endocrinology, 2015; 6.

51. Dey A., et al. Effects of oxytocin on neural response to facial emotion recognition in schizophrenia. In: Schizophrenia Bulletin. Great Clarendon St, Oxford Ox2 6dp, England: Oxford Univ Press, 2017; p. S75-S76.

52. Feldman R., et al. Oxytocin pathway genes: evolutionary ancient system impacting on human affiliation, sociality, and psychopathology. Biological Psychiatry, 2016; 79.3: 174-184.

53. Montag C., Brockmann E.B., Bayerl M., et al. Oxytocin and oxytocin receptor gene polymorphisms and risk for schizophrenia: a casecontrol study. World J. Biol.Psychiatry, 2013; 14(7): 500-508

54. Souza R.P., Ismail P., Meltzer H.Y., Kennedy J.L. Variants in the oxytocin gene and risk for schizophrenia. Schizophr. Res., 2010; 121: 279-280.
55. Souza R.P., et al. Schizophrenia severity and clozapine treatment outcome association with oxytocinergic genes. Int J Neuropsychopharmacol., 2010; 13:793-8.

56. Goldman M., Marlow-O'Connor M., Torres I., Carter C.S. Diminished plasma oxytocin in schizophrenic patients with neuroendocrine dysfunction and emo-tional deficits. Schizophr Res., 2008; 98:247-55.

57. Goldman M.B. Brain circuit dysfunction in a distinct subset of chronic psychotic patients. Schizophrenia Research, 2014, 157.1: 204-213.

58. Rubin L.H, et al. Peripheral oxytocin is associated with reduced symptom severity in schizophrenia. Schizophr Res., 2010; 124:13-21.

59. Rubin L.H., et al. Sex-specific associations between peripheral oxytocin and emotion perception in schizophrenia. Schizophr Res., 2011; 130:266-70.

60. Feifel D., Shilling P. D., MacDonald K. A review of oxytocin's effects on the positive, negative, and cognitive domains of schizophrenia. Biological psychiatry, 2016; 79(3), 222-233.

61. Rubin L.H., et al. Reduced levels of vasopressin and reduced behavioral modulation of oxytocin in psychotic disorders. Schizophrenia bulletin, 2014; 40.6: 1374-1384.

62. Rubin L.H, Carter C.S, Bishop J.R, Pournajafi-Nazarloo H, Harris M.S, Hill S.K, et al. Peripheral vasopressin but not oxytocin relates to severity of acute psychosis in women with acutely-ill untreated first-episode psychosis. Schizophr Res. 2013; 146(1-3):138-43.

63. Sasayama D., Hattori K., Teraishi T., Hori H., Ota M., Yoshida S., et al. Negative correlation between cerebrospinal fluid oxytocin levels and negative symptoms of male patients with schizophrenia. Schizophrenia research, 2012, 139.1: 201-206.

64. Jobst A., Dehning S., Ruf S., Notz T., Buchheim A., Henning-Fast $K$., et al. Oxytocin and vasopressin levels are decreased in the plasma of male schizophrenia patients. ActaNeuropsychiatr. 2014; 26(6):347-55.

65. Keri S., Kiss I., Kelemen O. Sharing secrets: oxytocin and trust in schizophrenia. SocNeurosci. 2009; 4(4):287-93. 795449706

66. Haram M, Tesli M, Bettella F, Djurovic S, Andreassen OA, Melle I. Association between Genetic Variation in the Oxytocin Receptor Gene and Emotional Withdrawal, but not between Oxytocin Pathway Genes and Diagnosis in Psychotic Disorders. Front Hum Neurosci. 2015; 9:9

67. American Psychiatric Association, et al. Diagnostic and statistical manual of mental disorders (DSM-5). American Psychiatric Pub., 2013; s. 87-122.

68. Bellack A.S., et al. Remediation of cognitive deficits in schizophrenia. The American journal of psychiatry, 1990;147.12: 1650

69. Taylor, M. A.; Abrams, R. Cognitive impairment patterns in schizophrenia and affective disorder. Journal of Neurology, Neurosurgery\& Psychiatry., 1987; 50.7: 895-899.

70. Penn D.L., Addington J., Pinkham A. Zaburzenia poznania społecznego. W: Lieberman J., Stroup T.S., Perkins D.O. red. Schizofrenia. Washington, DC, London, UK: American Psychiatric Publishing Inc., 2006; s. 263-278.

71. Fett A.K., et. al. The relationship between neurocognition and social cognition with functional outcome in schizophrenia: a metaanalysis.Neurosci. Biobehav. Rev., 2011; 35(3): 573-588.

72. Wiener D., et al. Zaburzenia teorii umysłu oraz empatii w schizofrenii i chorobie afektywnej dwubiegunowej. Neuropsychiatria i Neuropsychologia, 2011; 6.2: 85-92.

73. Evangeli M., Broks P. Face processing in schizophrenia: parallels with the effects of amygdala damage. Cognit. Neuropsychiatry, 2000; 5: 81-104. 
74. Gur R.E., McGrath C., Chan R.M. iwsp. An fMRI study of facial emotion processing in patients with schizophrenia. Am. J. Psychiatry, 2002; 159: 1992-1999.

75. Haxby J., Hoffman E., Gobbini M. The distributed neural system for face perception. Trends Cognit. Sci., 2000; 4: 223-233.

76. Hellewell J.S. Affect judgement and facial recognition memory in schizophrenia. Psychopathology, 1994; 27: 255-261.

77. Człapa K., Wysok D., Rybakowski F. Deficyty poznania społecznego w zaburzeniach ze spektrum autyzmu -porównanie ze schizofrenią. Neuropsychiatry \& Neuropsychology, 2016;11(1):12-20.

78. Spychalska K., Kucharska-Pietura K. Kielan K. Neurobiologia społecznego poznania w schizofrenii. Psychiatria, 2004;1.1: 9-15.

79. Green M.F., Olivier B., Crawley J.N., Penn D.L., Silverstein S. Social cognition in schizophrenia: recommendations from the MATRICS new approaches conference. Schizophr. Bull., 2005; 31(4): 882-887.

80. Frith C.D., Frith U. The neural basis of mentalizing. Neuron 2006; 50(4): 531-534.

81. Górska D., Marszał, M. Mentalizacja i teoria umysłu w organizacji osobowości borderline -r óżnice pomiędzy afektywnymi i poznawczymi aspektami poznania społecznego w patologii emocjonalnej. Psychiatria Polska, 2014; 48(3).

82. Tager-Flusberg H., Sullivan K. A componential view of theory of mind: evidence from Williams syndrome. Cognition, 2000; 76.1: 59-90.

83. Bora E., Yucel M., Pantelis C. Theory of mind impairment in schizophrenia: meta-analysis. Schizophrenia research, 2009; 109.1: 1-9.

84. Gavilán J.M., García-Albea J.E. Theory of mind and language comprehension in schizophrenia: Poor mindreading affects figurative language comprehension beyond intelligence deficits. Journal of Neurolinguistics, 2011; 24.1: 54-69.

85. Strauss G.P, Keller W.R., Koenig J.I., Sullivan S.K., Gold J.M., Buchanan R.W. Endogenous oxytocin levels are associated with the perception of emotion in dynamic body expressions in schizophrenia. Schizophr Res. 2015; 162(1-3):52-6.

86. Averbeck et al., 2011. Averbeck B.B., Bobin T., Evans S., and Shergill S.S.: Emotion recognition and oxytocin in patients with schizophrenia. Psychol. Med. 2011; undefined: pp. 1-8

87. Strauss G. P., Keller W. R., Koenig J. I., Gold J. M., Frost K. H., Buchanan R. W. Plasma oxytocin levels predict social cue recognition in individuals with schizophrenia. Schizophrenia Research, 2015162(0), 47-51

88. Walss-Bass, C., Fernandes, J. M., Roberts, D. L., Service, H., \&Velligan, D. Differential correlations between plasma oxytocin and social cognitive capacity and bias in schizophrenia. Schizophrenia research, 2013; 147(2), 387-392.

89. Davis M.C., Horan W.P., Nurmi E.L., Rizzo S., Li W., Sugar C.A, et al. Associations between oxytocin receptor genotypes and social cognitive performance in individuals with schizophrenia. Schizophr Res. 2014; 159(2-3):353-7.

90. Green M.F., Horan W.P., Lee J. Social cognition in schizophrenia. Nature Reviews Neuroscience, 2015; 16(10), 620-631.

91. Green, M.F., Harvey P.D. Cognition in schizophrenia: Past, present, and future. Schizophrenia Research: Cognition, 2014; 1(1), e1-e9

92. Frost K, Keller W, Buchanan R, Gold J, Koenig J, Ossenfort K, et al. Plasma Oxytocin Levels are Associated with Impaired Social Cognition and Neurocognition in Schizophrenia. Archives of clinical neuropsychology: the official journal of the National Academy of Neuropsychologists, 2014; 29(6):577-8.

93. Michalopoulou P. G., Averbeck B. B., Kalpakidou A. K., Evans S., Bobin T., Kapur S., Shergill S. S. The effects of a single dose of oxytocin on working memory in schizophrenia. Schizophrenia research, 2015; 162(1-3), 62 .
94. Feifel D., MacDonald K., Cobb P., Minassian A. Adjunctive intranasal oxytocin improves verbal memory in people with schizophrenia. Schizophrenia research, 2012; 139(1), 207-210.

95. Bujanow W. Is oxytocin an anti-schizophrenic hormone? Can. Psychiatr. Assoc. J., 1974; 19: 323.

96. Bujanow W. Hormones in the treatment of psychoses. Br Med J., 1972; 4(5835):298.

97. Fawtrel M, Loh K, Blake A, Ridout D, Hawdon J. Randomised, double blind trial of oxytocin nasal spray in mothers expressing breast milk for preterm infants. Arch. Dis. Child Fetal Neuonatal. Ed., 2006; 91: F169-F174

98. Sarnay Z, Kovacs GL. Role of oxytocin in the neuroadaptation to drugs of abuse. Psychoneuroendocrinol., 1994; 19: 85-117.

99. Domes, G.; Heinrichs, M.; Michel, A.; Berger, C.; Herpertz, S.C. Oxytocin improves "mind-reading" in humans. Biol. Psychiatry, 2007; 61: 731-733.

100. Feifel D, Macdonald K, Nguyen A. Adjunctive intranasal oxytocin reduces symptoms in schizophrenia patients. Biol. Psychiatry, 2010; 68 (7): 678-680.

101. Sherry D. F. Neuroecology. Annu. Rev. Psychol., 2006; 57: $167-$ 197.

102. Kaba H. Neurobiology of mmmalian olfactory learning that occurs during sensitive periods. Curr. Zool., 2010; 56: 819- 833.

103. McDonald K., McDonald T.M.: The peptide that binds: a systematic review of oxytocin and its prosocial effects in humans. Harv. Rev. Psychiatry, 2010; 18: 1-21

104. Walczewski K., Wojciechowska A. Sieci społeczne pacjentów chorych na schizofrenię $\mathrm{w}$ trzy lata po pierwszej hospitalizacji. Porównanie grupy objętej programem leczenia środowiskowego z grupą z indywidualnym programem leczenia. Psychiatria Polska., 1998; 32(1): 59- 69.

105. Fehm- Wolfsdof G., Born J., Voigt KH., Fehm HL. Human memory and neurohypophyseal hormones: opposite effects of vasopressin and oxytocin. Psychoneuroendocrinol., 1984; 9(3): 285- 292.

106. Baumgartner T., Heinrichs M., Vonlanthen A., et al. Oxytocin shapes the neural circuitry of trust and trust adaptation in humans. Neuron., 2008; 58(4): 693-650.

107. Anderson- Hunt M., Dennerstein L. Drug points: increased female sexual response after oxytocin. BMJ., 1994: 309- 928.

108. Teltsh 0 ., et al. Oxytocin and vasopressin genes are significantly associated with schizophrenia in a large Arab-Israeli pedigree. Int. J. Neuropsychopharmacol., 2012: 15, pp. 309-319.

109. Bigdeli T. B., et al. Comprehensive gene-based association study of a chromosome 20 linked region implicates novel risk loci for depressive symptoms in psychotic illness. PloS one, 2011, 6.12: e21440.

110. Gershon E. S.; Alliey-Rodriguez N.; Liu Ch. After GWAS: searching for genetic risk for schizophrenia and bipolar disorder. American Journal of Psychiatry, 2011, 168.3: 253-256.

111. Montag C., et al. Association between oxytocin receptor gene polymorphisms and self-rated 'empathic concern'in schizophrenia. PloS one, 2012, 7.12: e51882.

\section{Correspondence address}

Katarzyna Jusiak

I KlinikaPsychiatrii, PsychoterapiiiWczesnejInterwencji

ul. Głuska 1, 20-439 Lublin

Tel. 817487307

Otrzymano:14.09.2017

Zrecenzowano: 22.12.2017

Przyjęto do druku: 27.12.2017 